\title{
Exploring the Science of Marma - An Ancient Healing Technique - Part 1: Its Mention in Ancient Indian Scriptures
}

\author{
Alka Mishra*, Vandana Shrivastava \\ Department of Ayurveda and Holistic Health, Dev Sanskriti Vishwavidyalaya, \\ Gayatrikunj-Shantikunj, Haridwar, Uttarakhand, India
}

*Corresponding Author: Alka Mishra - Email: alka.mishra@dsvv.ac.in

\section{License information for readers:}

This paper is published online under the Creative Commons Attribution (CC BY 4.0) License, whose full terms may be seen at https://creativecommons.org/licenses/by/4.0/

Uploaded online: 27 June 2020

\begin{abstract}
Marma is an extremely important topic discussed in Ayurveda. Marma point is defined as anatomical site where muscles, veins, ligaments, bones and joints meet together. These are very important vital places, that are the 'seats of life' (Prana - the vital life force). Any injury to these parts may lead to severe pain, disability, loss of function, loss of sensation and death. Therefore, it has been stated in scriptures that these vital points should not be injured, and should be kept intact even while doing surgeries. However, recent researches indicate that if any Marma point is inflamed or painful, then stimulating its nearby Marma points can help in alleviating this pain. Several studies and texts have reported the therapeutic benefits of Marma Therapy in treating various physical and mental disorders.

Looking at the importance of Marma Science with regards to surgeries, as well as their recent use and future possibilities as an effective therapeutic procedure, the present study was undertaken for an in-depth study of the Science of Marma. The present article, which is Part-1 of this study, gives an account of various ancient / classical Indian scriptures, including the Vedas, Upanishads, Puranas, Epics, Samhitas, etc., that mention different aspects of the Science of Marma. Both the spiritual aspects and complete anatomical description of Marmas are available in these scriptures. It is observed that the knowledge of Marmas was being extensively used for various purposes like warfare, self-defense, surgery, etc., ever since the Vedic age.
\end{abstract}

Keywords: Ayurveda, Marma Science, Marma Therapy, Ancient Scriptures, Veda, Upanishad, Samhita, Purana 


\section{Introduction}

Marma is an extremely important topic discussed in Ayurveda. Marma point is defined as anatomical site where muscles, veins, ligaments, bones and joints meet together (Sushruta Samhita Sharira Sthana 6/16) [1]. According to Acharya Sushruta there are 107 marmas in human body (Sushruta Samhita Sharira Sthana 6/3) [1]. These are very important vital places, that are the 'seats of life' (Prana - the vital life force) (Ashtanga Hridaya Sharira Sthana 4/2) [2]. Any injury to these parts may lead to severe pain, disability, loss of function, loss of sensation and death [3]. It plays an important role in surgery; therefore, it is called 'Shalya Vishayardha' (fifty percent of the entire science of surgery) (Sushruta Samhita Sharira Sthana 6/35) [1]. Acharya Sushruta states that Marma sthana, a very vital point, should not be injured and should be kept intact even while doing surgeries (Sushruta Samhita Sharira Sthana 6/21) [1].

However, recent researches indicate that if any Marma point is inflamed or painful, then stimulating its nearby Marma points can help in alleviating this pain [4]. Several studies and texts have reported the therapeutic benefits of Marma Therapy in treating various physical and mental disorders [3-23].

Looking at the importance of the Marma Science with regards to surgeries, as well as their recent use and future possibilities as an effective therapeutic procedure, the present study has been undertaken for an in-depth study of the Science of Marma.

The Science of Marma has been described in detail in various ancient / classical Indian texts including the Vedas, Upanishadas, Puranas, Samhitas, etc. [3-10,22-35]. The present article, which is Part-1 of this study, gives an account of various ancient / classical Indian scriptures that mention different aspects of the Science of Marma.

\section{Marma in Vedas}

\subsection{Rigveda}

Rigveda mentions the use of varma or protective covering for providing protection to the marmas [7]. It also states that the best form of protection (varma) for the marmas is prayer or mantra, which is indicative of the spiritual aspects of this ancient science [7].

मर्माणि ते वर्मणा छादयामि सोमस्त्वा राजामृतेनानु वस्ताम् ।

उरोर्वरीयो वरुणस्ते कृणोतु जयन्तं त्वानु देवा मदन्तु ।। (Rigveda 6/75/18) [36]

Meaning - $\mathrm{O}$ rider of the chariot! We cover your marma points by a protective shield or body armor.

\section{अस्मा इदु त्वष्टा तक्षद्वज्रं स्वपस्तमं स्वर्यं रणाय । \\ वृत्रस्य चिद्विद्येन मर्म तुजन्नीशानस्तुजता कियेधा: ।। $\quad$ (Rigveda 1/61/6) [36]}

Meaning - The destroyer of enemies, immensely powerful deity Indra, killed the demon Vritra by hitting at his marma sthan (vital spot) with that Vajra (weapon).

\subsection{Atharvaveda}

मर्माणि ते वर्मणा छादयामि सोमस्त्वा राजामृतेनानु वस्ताम् ।

उरोर्वरीयो वरुणस्ते कृणोतु जयन्तं त्वानु देवा मदन्तु ।। (Atharvaveda 7/123/1) [37]

The verse 7/123/1 given above talks about protecting the marma points by a protective shield or body armor.

पराद्य देवा वृजिनं शृणन्तु प्रत्यगेनं शपथा यन्तु सृष्टा: ।

वाचास्तेनं शरव ऋच्छन्तु मर्मन् विश्वस्यैतु प्रसितिं यातुधान: ।। $\quad$ (Atharvaveda 8/3/14) [37]

संवत्सरीणं पय उस्रियायास्तस्य माशीद् यातुधानो नृचक्ष: ।

पीयूषमग्रे यतमस्तितृप्सात् तं प्रत्यन्चमर्चिषा विध्य मर्मणि।। $\quad$ (Atharvaveda 8/3/17) [37]

मर्माविधं रोरुवतं सुपर्णेरदन्तु दुश्चितं मृदितं शयानम्। 
The verses $8 / 3 / 14,8 / 3 / 17$ and $11 / 12 / 26$ given above talk about attacking the marma points of the enemies with arrows, and shattering them. It is also evident from verses $8 / 3 / 14$ and $8 / 3 / 17$ that Agni (fire) was used as the ultimate weapon to destroy marma.

The verses $8 / 5 / 7,8 / 5 / 18$ and $8 / 5 / 19$ mention protecting one's body parts with varma (protective shield or body armor).

\section{आथर्वणीरांगिरसीर्देवीर्मनुष्यजा उत। ओषधय: प्रजायन्ते यदा त्वं प्राण जिन्वसि ।। (Atharvaveda 11/6/16) [37]}

Meaning - O Prana! when you satisfy (everyone) by pouring down as rain, then all the medicinal herbs, that have been created by Maharshi Atharva, produced by the descendants of Maharshi Angira and the deities, and cultivated by human beings, are manifested.

Prana is the vital life force that governs all the physical and subtle processes of a living being [38-41]. Marmas are the seats of Prana - verse 11/6/16 given above states the importance of Prana.

\section{Marma in Upanishadas}

Several Upanishadas like Shandilyopanishada, Garbhopanishada, Kshurikopanishada, etc. provide information about to the conceptual and anatomical aspects of marma points.

\subsection{Garbhopanishada}

"सप्रोतरं मर्मशतं" (Garbhopanishada 5) [42]

Garbhopanishada states that the human body consists of 107 marmas (weak or sensitive spots) (according to verse 5 given above), 180 sutures or junction points, 109 snayu (ligaments), 700 sira (channels), 500 majja (muscle), 360 bones, and forty five million hairs [42].

\subsection{Shandilyopanishada}

अष्टादशसु मर्मस्थानेषु क्रमाद्धारणं प्रत्याहार: । (Shandilyopanishada 1/8/1)[43]

Meaning - Doing dharana (establishing deep linkage of the inner consciousness with the divine currents present at those locations and experience the resulting divine feelings) one by one on the eighteen marma locations is called pratyahara.

\section{पादांगुष्ठगुल्फ़जंघाजानूरुपायुमेढनाभिह्टदयकण्ठकूपतालुनासाक्षिभूमध्यललाटमूर्धिस्थानानि।}

तेषु क्रमादारोहावरोहक्रमेण प्रत्याहरेत् ।I" (Shandilyopanishada 1/8/2)[43]

Meaning - The names of the eighteen marma locations have been told here as - big toe, gulpha, jangha, janu, uru, guda, linga, nabhi, hridaya, kanthakupa, talu, nasika, akshi, bhroomadhya, lalaata, murdhni - on all these locations pratyahar should be done in the order of going up and down.

\subsection{Kshurikopanishada}

पादस्योपरि यन्मर्म तद्रूपं नाम चितयेत् । मनोद्वारेण तीक्ष्णेन योगमाश्रित्य नित्यश: ।। (Kshurikopanishada 12) [43] इन्द्रवज्र इति प्रोक्तं मर्मजंघानुकृन्तनम् । तद्ध्यानबलयोगेन धारणाभिर्निकृन्तयेत् |। (Kshurikopanishada 13) [43] ऊर्वोर्मध्ये तु संस्थाप्य मर्मप्राणविमोचनम् । चतुरभ्यासयोगेन छिन्देदनभिशंकित: ।। (Kshurikopanishada 14) [43]

Meaning - Contemplate upon the name and form of the marma locations of the legs. By daily taking help of yoga, and with a sharp mind, pierce the area named 'Indravajra' which is located next to the thighs. There, in between the urus (thighs), establish the prana (that specifies the location of the marmas) with the combined effort of dhyan bal (meditation power) and dharana, by yoga become doubtless of the sharp dharana of the mind, and pierce the four marma locations (from the root plexus to the heart). 


\section{Marma in Puranas}

\subsection{Kurma Purana}

परक्षेत्रे गां धयन्तीं न चाचक्षीत कस्यचित् ।

न संवदेत् सूतके च न कश्चिन्मर्मणि स्पृशेत्।।

(Kurma Purana Uparivibhage 2/16/33) [44]

Kurma Purana mentions that the touching of marma points is prohibited [44].

\subsection{Agni Purana}

In chapter 370 (Sharira Avayava - parts of the body) of Agni Purana [45,46], 10 locations have been mentioned where the Prana resides - Murdha, Hridaya, Nabhi, Kantha, Jihvaa, Shukra, Rakta, Guda, Vasti, Gulpha - all these are marma points, as these are the seats of Prana.

\section{Marma in Brahmanas}

Brahmana Gratha like Shatapatha Brahmana describe the important marma locations, i.e. the navel, head and heart, as well as various Pranas, Dhatus and body organs [7].

\section{Marma in Epics} found.

In the great epics like Ramayana and Mahabharata, many references of Marma or Varman are

\subsection{Ramayana}

$$
\text { ततो मर्मसु मर्मज्ञो मज्जय्निशितांशरान् । रामलक्ष्मणयोर्वीरो ननाद च मुहुर्मुहु: ।। }
$$

(Valmiki Ramayana, Yuddha Kanda 45/15) [47]

Meaning - Meghnad, who had knowledge of marma points, hit arrows in all the tender body parts of ShriRamchandra ji and Lakshman ji, and started making deafening noises again and again.

\section{तौ संप्रचलितौ वीरौ मर्मभेदेन कर्शितौ ।}

(Valmiki Ramayana, Yuddha Kanda 45/18) [47]

Meaning - The great archer, Jagatpati (master of the world), Shri Ramchandra ji and Lakshman ji, who were severely perturbed by the piercing of the marma points, fell on the ground.

\section{चिक्षेप परमायत्तस्तं शरे मर्मघातिनम् । (Valmiki Ramayana Yuddha Kanda Pu. 111/16) [47]}

Meaning - In order to kill Ravana, ShriRamchandra ji held up the bow, and with great strength, shot the arrow that would pierce and destroy all the Marma points.

\subsection{Mahabharata}

The great epic Mahabharata contains many references of marma or varma (Bhishma Parva 114/56, 119/5, 119/47, 119/61, 119/65) [48], (Drona Parva 92/7, 92/22), (Karna Parva 19/61), (Shalya Parva 32/63, 36/64), etc. [49].

It mentions the use of protective coverings for the marmas of both the soldiers, and the animals used in warfare like the elephants and horses [7]. Warriors were capable of using their Prana and Mantras for empowering the fighting instruments (like arrows) with the natural forces like fire [7]. There were several great warriors who could only be defeated if their marma points were destroyed [7].

\section{Marma in Samhitas}

The description about the number of marmas, their location, structures involved, along with the detailed explanation of marmaghata or viddha lakshanas and diseases is given in almost all the classical texts written during Samhita kala. All the Acharyas accepted that the total number of marmas is 107 . 


\subsection{Charaka Samhita}

Acharya Charaka has assigned great importance to Trimarmas, i.e. Basti, Hridaya and Shirah; he has also accepted the total number of marmas to be 107 in (Charaka Siddhi Sthana 9/1) and (Charaka Chikitsa Sthana 26/3) [50].

सप्तोतरं मर्मशतम् ।

(Charaka Siddhi 9/1) [50]

मर्माणि बस्तिं हृदयं शिरश्च प्रधानभूतानि वदन्ति तज्ञाः। (Charaka Chikitsa 26/3) [50]

In Sharira Sthana, Chapter 7 (7/9), Acharya Charaka told about ten seats of Prana; out of these, he considered the first six as marmas [50].

दश प्राणायतनानि; तद्यथा - मूर्धा, कण्ठ:, हृदयं, नाभि:, गुदं, बस्ति:, ओज:, शुक्रं, शोणितं, मांसमिति।

तेषु षट् पूर्वाणि मर्मसंख्यातानि।।

(Charaka Sharira 7/9) [50]

Also in Sutra Sthana, Chapter 29 (29/3) (Dashapranayataniya addhyaya), he said that there are only ten seats where prana (vital life force) is located, i.e. two temples (shankha), three marmas (heart, bladder and head), throat (kantha), blood (rakta), semen (shukra), oja, anorectal region (guda) [50].

दशैवायतनान्याहु: प्राणा येषु प्रतिष्ठिता: ।

शंखौ मर्मत्रयं कण्ठो रक्तं शुक्रौजसी गुदम् ।।

(Charaka Sutra 29/3) [50]

In Sutra Sthana, Chapter 11 (11/48), Acharya Charaka has explained three passages of diseases - shakha (periphery), marmasthisandhi (vital spots along with bones and joints) and koshtha (stomach and intestine). Further he clarifies that marmas include basti (urinary bladder), hridaya (heart) and murdha (head), i.e. Trimarmas, and this is the middle passage of diseases [50].

त्रयो रोगमार्गा इति - शाखा, मर्मास्थिसन्धय:, कोष्ठश्च। (Charaka Sutra 11/48) [50]

Acharya Charaka has given the importance of Trimarmas in Siddhi Sthana $9(9 / 5)$. He stated that if any of the three marmas is broken, it leads to the rapid breaking of the entire body; this is because if the substratum is destroyed, then its dependent is also destroyed; their affliction leads to the appearance of severe disorders [50].

तेषां त्रयाणामन्यतमस्यापि भेदादाश्वेव शरीरभेद: स्यात्, आश्रयनाशादाश्रितस्यापि विनाशः;

तदुपघातात्तु घोरतरव्याधिप्रादुर्भावः। $\quad$ (Charaka Siddhi 9/5) [50]

\subsection{Sushruta Samhita}

Acharya Sushruta is considered as the 'Father of Indian Surgery'. He gave great importance to Marmas in reference to Shalya Chikitsa (surgery). He gave detailed description of Marmas, their types, numbers, location, measurement, anatomical structure, correlation with panchamahabhutas, symptoms if they get injured and their management, etc. [1]. He has devoted a full chapter to Marmas in Sharira Sthana as 'Pratyeka Marma Nirdesham Shaariram' (Chapter 6) [1].

\subsection{Ashtanga Hridaya}

The detailed reference about Marma is available in Ashtanga Hridaya. Laghu Vagbhatta mentioned about Marma in Sharira Sthana of Ashtanga Hridaya, Chapter 4 (Marma Vibhagam Shariram) [2].

\subsection{Ashtanga Sangraha}

Vriddha Vagbhatta explained Marma in Sharira Sthana of Ashtanga Sangraha, Chapter 7 [51,52]. In this chapter he explained the same view as that of Acharya Sushruta; the difference between the two is only in the structural classification. He added 'Dhamani Marma' along with other types of Marmas [51,52].

Acharya Vagbhatta have mentioned ten Pranayatana in the body (Ashtanga Sangraha Sharira 5/59) [51]. Out of these ten Pranayatana, seven are called as 'Mahamarmas' (very important marmas) 
(Ashtanga Sangraha Sharira 5/60) [51].

दश प्राणायतनानि मूर्धा जिह्बाबन्धनं कण्ठो हृदयं नाभिर्बस्तिगुद: शुक्रमोजो रक्तम् ।

एषामाद्यानि सप्त पुनर्महामर्मसंज्ञानि ।। (Ashtanga Sangraha, Sharira sthana 5/59,60) [51]

\subsection{Vashishtha Samhita}

Vashishtha Samhita (Chapter 3) mentions eighteen marma locations that are the seats of Prana, and describes Pratyahara as the Dharana (concentration) on these marmas [53].

\subsection{Kashyapa Samhita}

Acharya Kashyapa accepted total number of marmas as 107; however, just like Acharya Charaka, he gave more importance to three marmas, which he mentioned as 'Mahamarmani' in Sharira Sthana, Chapter 4 [54].

\subsection{Sharangadhara Samhita}

Acharya Sharangadhara mentioned total number of marmas as 107 in Chapter 5 of Purva Khanda (Kaladikhyanam). He told marmas as the base of life (5/39) [55].

\subsection{Bhava Prakasha}

Acharya Bhava Mishra gave a detailed description of Marma in Purva Khanda Chapter 3 (Garbha Prakarana Addhyaya), which is similar to the views of Acharya Sushruta. He told that Prana (vital life force) primarily resides in Marmas (3/223) [56,57].

\subsection{Madhava Nidana}

Acharya Madhava gave the types of Marmas, as well as their general and specific lakshanas of vedhana (Marma-viddha) in Saddyovrana Nidana Adhyaya, Chapter 43 [58].

\subsection{Yogaratnakara}

Yogaratnakara mentioned the general symptoms of Marma-kshata (injury or trauma that occur in five types of marma) in Uttarardha, Saddyovrana Nidana Adhyaya -18,19 [59].

\section{Conclusion}

Marma is an important topic discussed in Ayurveda, that has extreme significance with regards to surgeries, and is also the basis for Marma Therapy, an effective therapeutic procedure. With a view to explore the foundational elements of the Science of Marma, the present article gives an account of various ancient / classical Indian scriptures that mention different aspects of this Science. It is observed that the knowledge of Marmas existed ever since the Vedic age, and this knowledge was being extensively used for various purposes like warfare, self-defense, surgery, etc. Both the spiritual aspects and complete anatomical description of Marmas are available in these scriptures.

The description about the number of marmas, their location, structures involved, correlation with Panchamahabhutas, classification, along with the detailed explanation of marmaghata or viddha lakshanas (effect of trauma) is given in classical texts written during Samhita kala. These will be covered in detail in Part-2 of the exploration of the Science of Marma.

\section{Acknowledgements}

Authors would like to acknowledge the subtle guidance of their spiritual guide, Revered Pandit Shriram Sharma Acharya (http://www.awgp.org/about_us/patron_founder). The authors thank the faculty and staff of the Department of Ayurveda and Holistic Health at Dev Sanskriti Vishwavidyalaya, Haridwar for their support in conducting this study.

Compliance with ethical standards: The authors have maintained necessary ethical standards while conducting the research.

Conflict of interest: The authors declare that they have no conflict of interest. 


\section{References}

1. Murthy KRS. Susruta samhita. volume I, II, III. Varanasi, Uttar Pradesh, India: Chaukhambha Orientalia; 2008.

2. Gupta KA. Ashtanga hrdyam of vagbhata - vidyotini hindi commentary. Varanasi, Uttar Pradesh, India: Chaukhamba Sanskrit Sansthan; 2005.

3. Joshi SK. Marma science and principles of marma therapy. 1st ed. Haridwar, Uttarakhand, India: Vani Publications; 2010.

4. Joshi SK. Marma chikitsa vigyan (Hindi). Haridwar, Uttarakhand, India: Mrityunjay Mission; 2012.

5. Joshi SK. Marma vigyan evam chikitsa - vaidik chikitsa vigyan (Hindi). Haridwar, Uttarakhand, India: Mrityunjay Mission; 2011.

6. Joshi SK. Marma vigyan evam aushadhopachar dwara chikitsa (Hindi). Haridwar, Uttarakhand, India: Mrityunjay Mission; 2013.

7. Frawley D, Ranade S, Lele A. Ayurveda and marma therapy. Delhi, India: Chaukhamba Sanskrit Pratishthan; 2015.

8. Lad V, Durve A. Marma points of ayurveda. Albuquerque, New Mexico, USA: The Ayurvedic Press; 2015.

9. Schrott E, Raju JR, Schrott S. Marma therapy. (Translated by) Lorys M. London, UK: Singing Dragon; 2016.

10. Phull G, Phull R. Clinical approach to marma chikitsa. New Delhi, India: IP Innovative Publication Pvt. Ltd.; 2019.

11. Phull G, Phull R. Marma vigyana ka chikitsiya upayoga (Hindi). New Delhi, India: IP Innovative Publication Pvt. Ltd.; 2019.

12. Denaud P. Kalaripayat - the martial arts tradition of India. (Translated by) Cain J. Vermont, USA: Destiny Books; 2009.

13. Fox M, Dickens A, Greaves C, Dixon M, James M. Marma therapy for stroke rehabilitation - a pilot study. Journal of Rehabilitation Medicine. 2006;38(4):268-271. DOI: 10.1080/16501970600630820. (https://www.medicaljournals.se/jrm/content_files/download.php? doi $=10.1080 / 16501970600630820)$

14. Kotelevskiy VI. Integrative technology of massage manipulations in physical rehabilitation of students with backbone pathology. Pedagogics, Psychology, Medical-Biological Problems of Physical Training and Sports. 2016;20(3):31-40. http://dx.doi.org/10.15561/18189172.2016.0305. (https://www.sportpedagogy.org.ua/html/journal/2016-03/html-en/16kviwbp.html)

15. Murota M, Iwawaki Y, Uebaba K, Yamamoto Y, Takishita Y, Harada K, Shibata A, Narumoto J, Fukui K. Physical and psychological effects of head treatment in the supine position using specialized ayurveda-based techniques. The Journal of Alternative and Complementary Medicine. 2016;22(7):526-532.

DOI:

$10.1089 / \mathrm{acm} .2015 .0388$. (https://www.ncbi.nlm.nih.gov/pmc/articles/PMC4939366/)

16. Sieler R. Kalari and vaittiyacalai: medicine and martial arts intertwined. Asian Medicine. 2012; 7(1): $\quad$ 164-195. $\quad$ https://doi.org/10.1163/15734218-12341247. (https://brill.com/view/journals/asme/7/1/article-p164_7.xml?language=en)

17. Pathak AK. A study on anatomical concept of kurpara marma and its therapeutic application in grivavata (cervical spondylosis). Thesis for the degree of Doctor of Philosophy (Ph.D.) in Rachana Sharir. Varanasi, Uttar Pradesh, India: Banaras Hindu University; 2015. (https://shodhganga.inflibnet.ac.in/handle/10603/267960)

18. Dharmesh K. Optimization of individual performance in football by augmenting classical Indian marma therapy, kinesiology-taping and related physical excercises through supportive biomechanical parameter. Thesis for the degree of Doctor of Philosophy (Ph.D.) in Physical Education. Tiruchirappalli, Tamil Nadu, India: Bharathidasan University; 2017. (https://shodhganga.inflibnet.ac.in/handle/10603/220290)

19. Bedekar SS. A critical study of gulpha marma in basket ball players with special reference to the role of mash tail along with snehan and swedan as preventive measure. Thesis for the degree of Doctor of Philosophy (Ph.D.) in Ayurved. Pune, Maharashtra, India: Tilak Maharashtra Vidyapeeth; 2007. (https://shodhganga.inflibnet.ac.in/handle/10603/34851) 
20. Rajeshwari PN. A study on rujakara marma and management of viddha laxanas - a clinical study. Dissertation for the degree of Ayurveda Dhanwanthari (M.S.-Shalya Tantra). Bengaluru, Karnataka, India: Rajiv Gandhi University of Health Sciences; 2010. (http://52.172.27.147:8080/jspui/handle/123456789/6831)

21. Vivek J. A comprehensive study on marma \& acupuncture points and evaluation of their therapeutic importance. Dissertation for the degree of Master of Surgery (Ayurveda Dhanvantari) in Shalya Tantra. Bengaluru, Karnataka, India: Rajiv Gandhi University of Health Sciences; 2011. (http://52.172.27.147:8080/jspui/handle/123456789/4737)

22. Lele A, Ranade S, Frawley D. Secrets of marma - the lost secrets of ayurveda. Delhi, India: Chaukhamba Sanskrit Pratishthan; 2005.

23. Srivastava VK, Srivastava A. Hand book on marma and panchakarma therapy. Varanasi, Uttar Pradesh, India: Chaukhambha Orientalia; 2019.

24. Pathak AK. Anatomy of marma. (Editor) Awasthi HH. Varanasi, Uttar Pradesh, India: Chaukhambha Orientalia; 2014.

25. Mishra JN. Marma and its management. Varanasi, Uttar Pradesh, India: Chaukhambha Orientalia; 2016.

26. Govindan SV. Massage therapy for diseases of vital areas (marma treatment). New Delhi, India: Abhinav Publications; 2005.

27. Banjare H. Marma - eka adhyayana, acupressure chikitsa paddhati ke vishesha shandarbha me. Dissertation for the degree of Ayurveda Vachaspati (M.D. - Ayurveda) in Rachana Sharira. Raipur, $\begin{array}{lllll}\text { Chhattisgarh, India: Pt. Ravishankar Shukla University; } 2009 . & .\end{array}$ (https://shodhganga.inflibnet.ac.in/handle/10603/41426)

28. Ismail SMB. Marmas in ayurveda and their explanation according to modern anatomy. Thesis for the degree of Doctor of Philosophy (Ph.D.) in Ayurveda. Pune, Maharashtra, India: Savitribai Phule Pune University; 1984. (https://shodhganga.inflibnet.ac.in/handle/10603/145863)

29. Kumar CS. A comprehensive study of marmas with special reference to Ayurvedic and Tamil marma sastras in relation to its applied anatomy. Thesis for the degree of Doctor of Philosophy (Ph.D.) in Ayurveda. Kalady, Kerala, India: Sree Sankaracharya University of Sanskrit; 1999. (https://shodhganga.inflibnet.ac.in/handle/10603/136019)

30. Muley SK. Ayurvediya sanhitokta marma vichara, vaikalyakara marmanche mahatva evam janumarmachya vaikalyakaratvachi uparugna paddhatine punarpadatalani eka abhyasa (Marathi). Thesis for the degree of Doctor of Philosophy (Ph.D. - Ayurveda) in Sharira Rachana. Nanded, Maharashtra, India: Swami Ramanand Teerth Marathwada University; 2007. (https://shodhganga.inflibnet.ac.in/handle/10603/240135)

31. Parameswaran S. A comprehensive study on sandhi marma shareera w.s.r. to manibandha marma and its injuries (trauma). Dissertation for the degree of Doctor of Medicine (M.D. - Ayurveda) in Shareera Rachana. Bengaluru, Karnataka, India: Rajiv Gandhi University of Health Sciences; 2012. (http://52.172.27.147:8080/jspui/handle/123456789/7127)

32. Vijayanath V. A comprehensive study of marmas in the hasta (hand) w.s.r. to the surface and regional anatomy (cadaver dissection). Dissertation for the degree of Doctor of Medicine (M.D. Ayurveda) in Shareera Rachana. Bengaluru, Karnataka, India: Rajiv Gandhi University of Health Sciences; 2011. (http://52.172.27.147:8080/jspui/handle/123456789/4578)

33. Vipin PC. A comprehensive study on gulpha sandhi shareera w.s.r. to sports injuries. Dissertation for the degree of Doctor of Medicine (Ayurveda) in Shareera Rachana. Bengaluru, Karnataka, India: Rajiv Gandhi University of Health Sciences; 2011. (http://52.172.27.147:8080/jspui/handle/123456789/4579)

34. Thatte DG. Acupuncture, marma and other asian therapeutic techniques. Varanasi, Uttar Pradesh, India: Chaukhambha Orientalia; 2015.

35. Fedorova M. Die Marmantheorie in der klassischen indischen Medizin (German) (English translation of the title - the marma theory in classical Indian medicine). Thesis for the degree of Doctor of Philosophy (Ph.D.). Munich, Bavaria, Germany: Ludwig-Maximilians-Universität München;1990.

(https://archive.org/details/DieMarmantheorieInDerKlassischenIndischenMedizinFedorova1990/p age/n12/mode/2up 
36. Sharma S, Sharma BD. Rigveda samhita - saral Hindi bhavarth sahit - part 1 to 4 (Hindi). Gayatri Tapobhumi, Mathura, Uttar Pradesh, India: Yug Nirman Yojna Vistar Trust; 2014.

37. Sharma S, Sharma BD. Atharvaveda samhita - saral Hindi bhavarth sahit - part 1 to 2 (Hindi). Gayatri Tapobhumi, Mathura, Uttar Pradesh, India: Yug Nirman Yojna Vistar Trust; 2014.

38. Brahmavarchas. Pranashakti : ek divya vibhuti (Hindi). Pandit Shriram Sharma Acharya samagra vangamaya. volume 17. 2nd ed. Mathura, Uttar Pradesh, India: Akhand Jyoti Sansthan; 1998.

39. Sharma, S. Kaya me samaya, pranagni ka jakhira (Hindi). Gayatri Tapobhumi, Matura, Uttar Pradesh, India: Yug Nirman Yojana Vistar Trust; 2010. (http://literature.awgp.org/book/kaya_men_samaya_pranagni_ka_jakheera/v1.1)

40. Sharma, S. Kaya urja evam usaki chamatkari samarthya (Hindi). Gayatri Tapobhumi, Matura, Uttar Pradesh, India: Yug Nirman Yojana Vistar Trust; 2010. (http://literature.awgp.org/book/astonishing_power_of_physical_subtle_energy_of_human/v2.2)

41. Sharma, S. The astonishing power of the bio-physical and subtle energies of the human body. Haridwar, India: Shantikunj; 1996. (http://literature.awgp.org/book/astonishing_power_of_physical_subtle_energy_of_human/v1.1)

42. Joshi N. Garbhopanishada. Mumbai, Maharashtra, India: eBook Publication Pvt. Ltd.; 2016. (https://archive.org/details/garbhopanishad_201912/mode/2up)

43. Sharma S, Sharma BD. 108 Upanishad - brahmavidya khand - saral Hindi bhavarth sahit (Hindi). Gayatri Tapobhumi, Mathura, Uttar Pradesh, India: Yug Nirman Yojna Vistar Trust; 2015.

44. Singh CS. Koorma puran. Varanasi, Uttar Pradesh, India; Sarvabharatiya Kashirajanyasa; 1972. (https://archive.org/details/in.ernet.dli.2015.407407/mode/2up)

45. Vedavyas. Agni puranam (Sanskrit). Calcutta, India: Mora Prachya Shodhasansthan; 1957. (https://archive.org/details/in.ernet.dli.2015.430303)

46. Agni puran. [cited 2019 October 22]. (https://archive.org/download/agni-puran_201810/agni-puran.pdf)

47. Sharma D. ShrimadValmiki-Ramayan. Allahabad, Uttar Pradesh, India: Ramnarayan Lal; 1927. (https://archive.org/details/ShrimadValmikiRamayan-SanskritTextWithHindiTranslationDpSharma10/mode/2up)

48. Sharma R. The mahabharat - bhishm parv. Moradabar, Uttar Pradesh, India: Pandit Ramswaroop $\begin{array}{lll}\text { Sharma, Sanatandharma } & 1917 .\end{array}$ (https://archive.org/details/in.ernet.dli.2015.321082/mode/2up)

49. Pandey RS. Mahabharata (Hindi). Gorakhpur, Uttar Pradesh, India: Gita Press. (https://archive.org/details/Mahabharata_201712/mode/2up)

50. Sharma PV. Charaka-samhita (text with English translation). volume I, II. Varanasi, Uttar Pradesh, India: Chaukhambha Orientalia; 2008.

51. Gupta KA. Astanga samgraha (with Hindi commentary) (Hindi). part 1, 2. Varanasi, Uttar Pradesh, India: Chowkhamba Krishnadas Academy; 2016.

52. Murthy KRS. Astanga samgraha of Vagbhata (text, English translation, notes, indices, etc.). volume II - sarira, nidana, cikitsita and kalpa sthana. Varanasi, Uttar Pradesh, India: Chaukhambha Orientalia; 2018b.

53. Digambarji S, Jha P, Sahay GS. Vasistha samhita (yoga kanda). Lonavla, Pune, Maharashtra, India: Kaivalyadhama; 2017.

54. Bhisagacharya S. Kasyapa samhita (vrddhajivakiya tantra) (Hindi). Varanasi, Uttar Pradesh, India: Chaukhambha Sanskrit Sansthan; 2009.

55. Srivastava S. Sharngadhar samhita (jiwanprada Hindi commentary). 3rd ed. Varanasi, Uttar Pradesh, India: Chaukhambha Orientalia; 2003.

56. Misra B, Vaisya R. Bhavaprakasa of sribhava misra (including bhavaprakasa nighantu portion) edited with the 'vidyotini' Hindi commentary, notes and appendix - first part. Varanasi, Uttar Pradesh, India: Chaukhambha Sanskrit Bhawan; 2013.

57. Murthy KRS. Bhavaprakasa of bhavamisra. volume 1 - including nighantu portion. Varanasi, Uttar Pradesh, India: Chowkhamba Krishnadas Academy; 2016.

58. Sastri S. Madhava nidanam of sri Madhavakara (Hindi). part-II. 30th ed. Upadhyaya Y (revised and edited by). Varanasi, Uttar Pradesh, India: Chaukhambha Sanskrit Sansthan; 2001.

59. Sastri L. Yogaratnakara - with 'vidyotini' Hindi commentary (Hindi). (Editor) Sastri B. Varanasi, Uttar Pradesh, India: Chaukhambha Prakashan; 2018. 